Society of Mechanical Engineers on this Joint Committee are expecting to present again the proposed code, revised in coöperation with the representatives of the other societies, at the forthcoming Spring Meeting of the Society. The Committee still adheres to its plan of a Committee on Professional Conduct to enforce the code, and in fact regards this as an essential requirement.

The proposed code is printed in full on page 271.

It is the belief of many now within the American Society of Mechanical Engineers that success is now not far off. The forces operating for the adoption of the code have now reinforcements from an entirely different direction. The Committee on Constitution and By-Laws of the Society was requested two years ago to present to the Society an entire revision of the constitution and by-laws. This Committee has incorporated in the constitution an article headed "Professional Practice," the first section of which reads:

In all professional and business relations the members of the Society shall be governed by the Code of Ethics of the Society.

This section of the constitution is supplemented by the following by-law:
All members of the Society shall subscribe to the following Code of Ethics as required by the constitution:

(Here is to be inserted the new Code of Ethics when adopted by the Society.)

There follows a second paragraph in the by-laws:

All matters in connection with the administration of the Code of Ethics shall be in charge of the Standing Committee on Professional Conduct under the direction of the Council.

The duties of the proposed new Standing Committee on Professional Conduct are prescribed in the following proposed new by-law:

The Standing Committee on Professional Conduct shall, under the direction of the Council, have supervision of all matters relating to the Code of Ethics and its enforcement, as required by the constitution, and as detailed in the rules. The Committee shall consist of five members and the term of one member shall expire at the close of each Annual Meeting.

These matters of the Constitution and by-laws are likewise to come before the Society at the forthcoming spring meeting.

The work on a Code of Ethics for Mechanical Engineers has, therefore, consumed twelve years to date, and has now the prospect of full realization.

\title{
Ethics of the Engineering Profession
}

\section{By Frederick Haynes Newell}

United States Reclamation Service, Washington, D. C.

$\mathbf{N}$ its ideals the engineering profession is not surpassed by those of any other group of public servants. In practice, however, because these ideals are so altruistic, it has been found difficult to reduce them to a brief statement and to secure general agreement upon such statement. Most attempts to produce a brief code comparable with the Decalogue have resulted in little more than an expansion of the Golden Rule, such, for example, as is the code of ethics adopted by the American Society of 
Civil Engineers on September 2, 1914..$^{1}$

There has been much discussion by engineers of the need of adopting a comprehensive code in order that the ideals of the profession may be presented clearly to the young engineer. On the one hand, these efforts have been scoffed at; indeed, in the case of one of the national engineering societies, it was "decided that no gentleman needed a code of ethics, and that no code of ethics would make a gentleman out of a crook." At the other extreme, there are elaborate results, such as those of the American Institute of Electrical Engineers and other organizations, quoted by Daniel W. Mead. ${ }^{2}$

The chief difficulty in agreeing upon and adopting a code of ethics for the entire engineering profession has arisen from the fact that there is little agreement, even among engineers, as to the meaning or limitations of the words "engineer" and "engineering," and of the word "profession" as applied to engineering. In the evolution of the English language, the word "engineer" has come into such common use and has been made to include so many different practices that it is now necessary to use some qualifying adjective in order to have a common understanding as to what is meant when using this term.

\section{Gradations of the Term, Engineer}

In contrast, there is little relative difference in conception when we speak about an architect. This is a term which applies to a rather limited body of professional men, and, moreover, it has been defined by law. In contrast with this, the word "engineer" as employed by a professional engineer has an entirely different

${ }^{1}$ For this code, see Appendix, page 273.

2 "Contracts, Specifications and Engineering Relations." Daniel W. Mead, New York, McGraw Hill Book Company, 1916. meaning from that understood by the general public or as interpreted by court decision.

In Great Britain the engineer is a mechanic, and, in legal usage, is a man who operates an engine. The organizations of engineers in Great Britain are to a large extent comparable with trade unions in America. In the United States there are possibly a halfmillion men who, in common usage, are known as engineers, and yet none of whom would be eligible for membership in one of our great engineering societies. The engineer, as the word is popularly used, may be a mechanic, a tradesman, or a professional man. The division between these groups is broad, and it is almost impossible to draw a sharp line.

Some of the best known professional engineers in the United States, prominent in the affairs of technical engineering societies, are themselves business men as well as engineers, managing or controlling directly or indirectly large corporations which construct, build, or sell engineering works, machinery, or power. Many of the leaders have come up through the ranks, and at one time or another have been draftsmen or mechanics, and as such have been eligible for membership in labor unions, even if they have not actually taken out a card. Others, educated in the best engineering schools and for a time serving as professional engineers, have become business men and have gone into contracting or trade relations without losing their standing as professional engineers.

Yet, in spite of these uneven gradations, there is an attempt made at all times to hold before the eyes of the professional engineer certain standards of conduct which differentiate him from the business man, contractor or mechanic. He cannot go so far as the 
architects in acquiescing to the first rule of their code of ethics, which states that it is unprofessional for an architect "to engage directly or indirectly in any of the building trades." In fact the rigid adoption of such a rule might bring under the ban some of the most prominent members of the engineering profession, owners or partners in engineering corporations, nor has it been found practicable by engineers to follow the architects in their declaration that it is unprofessional to advertise. This drastic rule has been softened by the statement of the civil engineers that it is inconsistent with honorable and dignified bearing "to advertise in self-laudatory language, or in any other manner derogatory to the profession."

The ethical code of the engineer has been founded upon such long experience as has demonstrated that "honesty is the best policy." There may be, and doubtless are, many members of the profession who would prefer to consider that their ethics were purely altruistic and based upon the idealism of Kant, following his stern precepts of absolute devotion to duty and of self-negation. Such men there are in every profession, but the code of ethics has been evolved not by these stern idealists, but rather by the appeal to common sense and fair play, necessitated by the so-called practical conditions that surround the profession. Thus the civil engineers make the prohibition not against advertising but against carrying advertising to the point of self-laudation.

Because of the difficulty, found by the different branches of the engineering profession, in agreeing upon a common code, there has been a tacit agreement upon the point that the only way to perfect a code of engineering ethics is to follow the precedent of the British Institution, namely, to make decision upon specific questions as they arise, the body of decisions thus furnishing a code which it has been found impossible to write out and to agree upon in advance. Such decisions reveal the underlying principles and can be appealed to in other cases until these principles thus become firmly established in the minds of all concerned.

\section{The Case Method of Code BuILding}

This so-called "case" or project method of building up a code has been put into practice by the American Institute of Consulting Engineers and by the American Association of Engineers. In both of these organizations, composed largely of civil engineers, a simple code has been adopted, and then, as specific cases arise which seem to need consideration, each of these has been considered on its merits and a decision published, stating, without giving names, the facts of the case and the conclusion reached by the Practice Committee. As these cases increase in number and cover more and more widely the conditions which occur in actual practice, there must result a better comprehension, not only of the ideals of the profession, but of the way in which these may be put into effect.

There are thus taken up and considered in succession, numerous questions regarding professional conduct as these arise between members or in daily contact with federal, state, or local officials and business men. The simpler personal matters are passed over quickly by the Practice Committee, but those involving the application of an important principle of ethics are given full consideration and are ultimately published without name. They thus form the basis for general discussion and become interwoven in 
the thought of engineers. The decisions result in a body of practice which in effect performs the function of a code of ethics, a code based upon positive or experimental data.

"It is certain that while experience has shown that an authorized and definite code of conduct is generally subversive of moral stamina through its absorption of personal responsibility, still ethics must be made work-a-day to a considerable degree, for they can then, if not slavishly followed, serve as guiding lights, or as points of departure, when a particular situation finds an individual unprepared by his own experience."

Of course, no code can satisfy all conditions. As has been stated, "Engineering, like war, is in practice a far more developed complex than when considered speculatively and coldly as a science. When it enters the world of commerce, it gathers the burdens of human nature. Its problems become those of business as well as those of the laboratory." ${ }^{3}$

\section{Engineering as a Profession}

There has always been, and probably always will be, a wide difference of opinion as to whether or not engineering is a learned profession comparable to law, medicine and the ministry. There are plenty of examples of devotion to ideals and of a purely professional attitude of mind in engineers comparable to that of any body of men in any one of the older professions. On the other hand, the advocates of the view that engineering is not a profession point to the facts, above noted, that the great body of men who are called engineers are by no means professional men, but are actively engaged in the ordinary business of life. 409.

Engineering Record, March 17, 1917, page
Various organizations of engineers have attempted from time to time to meet this condition, and, as they term it, "to raise the standard" of the profession. Great care is taken in passing upon the credentials offered and in admitting the applicants to full membership, with the idea that in so doing there will be segregated from the great mass of so-called engineers a rather select group who in their professional characteristics will be comparable to an equal number of members of one of the other professions. The principal difficulty, however, arises, as before indicated, in the fact that engineering is entering more and more definitely into the life and business of the ordinary citizen, so that the leaders in the profession often become drawn into executive positions, dealing in a large way with business affairs. Thus arises the anomalous situation in which leaders who may have passed through the professional stage of life have now evolved into business men and are conducting great corporate efforts, especially public utilities, along lines which, in the popular mind at least, are not compatible with the code of ethics which should be followed by the younger applicant for admission to the organization.

Engineering is a profession in the same sense that pure mathematics is a science, but the value of engineering to the human race is so great and so dependent upon practical application to every-day life that the profession, and the professional man if successful, becomes immersed in business relations.

\section{Group Organization Among Engineers}

The history of the organization of engineers is of interest, as illustrating the continual struggle between idealism on the one hand, which would produce a well-rounded code of ethics and, on 
the other, the practical considerations which have made such a code impossible of acceptance by all kinds of professional engineers. The first notable attempt at organization was made in the city of Boston and resulted in 1848 in what is now the oldest engineering society in the United States-the Boston Society of Civil Engineers. This association is carefully guarded in its membership; it attempts to preserve the highest possible professional standards among a type of engineers and of people readily recognized, wherever met in any part of the world, as distinctly "New England." The traditional New England conscience and thoroughness have triumphed through all the decades and have set a model for other engineering organizations, for, on examining the constitutions adopted by nearly every subsequent society, it will be seen that the phraseology of the Boston society has formed the groundwork.

Next in time was the organization in New York in 1852 of the American Society of Civil Engineers, which followed upon the excellent precedents already established. This organization has grown steadily and has adhered largely to its early standards, rigidly holding to these and in effect excluding the great body of practising engineers. It has thus forced the organization of many other rather specialized national societies, several of which have exceeded it in number of members.

It is to be noted that the Boston Society and that in New York were obliged even at that early date to use the qualifying word "civil" as separating the members not only from the military engineers but from the mechanical engineers, as well as from the engine runners, such as locomotive engineers, who in turn have formed the most powerful trade union of the country.

The tendency to restrict the use of the words "civil engineers" to a rather narrow group of men interested in bridges and other large structures, rivers and harbors, waterworks, sewage and roads, finally forced the rapidly widening groups of engineers who were interested in mechanical lines to form the American Society of Mechanical Engineers; and, because of the fashion thus set, the American Institute of Electrical Engineers then separated themselves from the other engineers. The mining men also found that the requirements for admission to the American Society of Civil Engineers were too restrictive, and they in turn formed the American Institute of Mining Engineers. The requirement for membership in the latter society was so different from that of the older American Society of Civil Engineers that for over a decade the older society refused to come under the same roof, largely because of the feeling that there was not sufficient restriction as regards professional standing in the great body of members of the society of miners.

Thus have been formed many national societies of civil engineers, as distinct from military engineers, divided by somewhat arbitrary technical lines, for the civil engineer frequently has to do with the mechanical and electrical devices or structures of the mechanical and electrical engineers, or vice-versa. These divisions have arisen largely from the divergent views as to requirements for admission to the national society. At the same time many state organizations have been formed, largely political in character in the sense that the laws of each state, differing from those of its neighbors, necessitated consideration of engineering matters, such as drainage, 
road-building, water works, and sewage, in their relation to the geographic and political entity of the state. These state societies have necessarily been organizations not of civil engineers alone but of men practising the profession of engineering. They include in their membership a large proportion of so-called practical men, surveyors and others who have picked up the work and have been educated not in engineering schools but in the "college of hard knocks."

In each of the principal cities of the United States it has also been found desirable to bring together men who practise engineering, in order to increase acquaintance and to discuss engineering problems with particular reference to local conditions. There are also in each city small groups of members of the national societies, either meeting separately or occasionally coöperating with each other and with the local society of engineers, many of whose members are frequently not eligible for membership in the national organizations.

Thus, a list of engineering societies will include a dozen or more national organizations, a score or more of state engineering societies, and a hundred organizations, one or two in each of the principal cities, each with different standards, coöperating occasionally or competing for membership.

The listing of engineering societies is complicated by the fact that there are many organizations, some incorporated, of men who as in the case of the socalled "sanitary engineers" may or may not be engineers according to the definition accepted. Some of the "sanitary engineers" are simply successful plumbers who may or may not have had an education in the theory of engineering, but who are practical business men.

\section{Need for Standards of Engineering} CoNDUCT

The reason for the creation of standards is evident from the brief review above given. The older, more conservative societies believe that it is of the highest importance to the public and to the profession that certain standards be set up and carefully observed. Their concern is mainly for creating and preserving a certain prestige and for rigidly excluding the applicants who do not meet this standard. At the same time, internally these older organizations are continually shaken and their growth and influence often reduced by the interminable struggle between the two factions, since the conservatives are continually trying to raise the standard as against the efforts of the progressives who are looking towards the wider influence of the larger society. On the part of these liberals it is urged that every man who is making a living by the practice of engineering should become a member and, as such, be educated and impressed with high standards by contact with men within the society, and not be forced to the alternative of joining a labor union if he desires to do his part toward improving the condition of his fellow engineer.

The reasons for the creation of the "standards" are those which underlie the ideals of the closed shop which, originated by the medical profession, have been adopted in large part by the lawyers and put into still wider effect by the labor unions, who have become most apt pupils in this regard. The engineering profession, as a whole, may be said to alternate between the ideals of an open, competitive business on the one hand, and, on the other, a restricted, licensed, or registered group, such as that of the lawyers and doctors, or 
the closed shop of the labor unions, each professing to seek the highest service to humanity through raising and maintaining certain group standards.

\section{Activities of Civil Engineering SocIETIES}

Considering the members of the civil engineering profession and the group action taken by them, it is to be noted that as such they have not attempted to coöperate very widely in their activities with other bodies of engineers, such as the mechanical, the electrical, or the mining. There has been a conscious effort in most organizations of civil engineers to bring together only "the best people" and to realize the ideals of the old Greek term, "aristocracy," in its best sense. Each society of civil engineers has pursued its own way, and the largest, the American Society of Civil Engineers, has kept out of most "entangling alliances." Though persuaded at a late date to make its home on top of the Engineering Societies' Building, it has not taken such action as, in the opinion of the majority of its members, would reduce its standards to those of its neighbors on the lower floors of the building. Thus it has up to the present time kept out of the Federation of American Engineering Societies, though coöperating with some of the societies in specific matters.

In spite of this somewhat exclusive attitude, the civil engineers have entered into conferences, one of the most notable of these being the Joint Committee on a Code of Ethics for Engineers, consisting of representatives of the American Society of Civil Engineers and four other national engineering organizations. The report of the Joint Committee, together with the proposed code, is included elsewhere in this volume. ${ }^{4}$

${ }^{4}$ See Article by Mr. Christie, page 101.
As regards publications, there has been practically no coöperation among the civil engineering societies, but each has issued its own annual or periodical literature, differing in general style and presentation from that of other similar bodies.

\section{General Type of Civil EngINeEring Socteties}

While there are a considerable number of civil engineering societies such as those mentioned, the Boston, the American, the Canadian, and others, national, state and city, there is a similarity in their type and activities, since, as above indicated, each in turn has been patterned largely upon the predecessors.

The standards for admission to membership in the civil engineering societies as such have usually been considered somewhat more restrictive than those for admission to other engineering societies, following in this respect the standard set by the Boston Society and the larger American. Many professional engineers, looking back over the history of the profession, regard this attempt at creating and maintaining a high but rather narrow standard as one of the misfortunes of the profession, as it would have been possible, a few decades ago, to have brought in and kept in one great national society, all of the engineers, mechanical, electrical, mining, chemical, etc., thus having a body which in strength and influence would have been comparable with the American Bar Association.

Divided, however, as are the engineers in these many specialized or technical societies, they, as a group, exercise a minimum of influence in public affairs. It may be said that until the mining engineer, Herbert Hoover, with his remarkable personality, came to the front, the engineer as 
such was little known or regarded in public affairs. He had been considered as the "hired man," and almost never served as a leader in commissions or on other public bodies. This condition is traceable in part to the fact that the engineers, following the standards which they have set, have not made their strength felt in the large affairs of the state and nation.

\section{Financial Support}

All civil engineering societies are supported by annual membership dues, these being employed in large part in payment of the salary of a secretary and in the cost of correspondence and publication. A few of the older societies have accumulated a substantial sinking fund, while other civil engineering bodies are adopting the principle of reinvesting the money for the benefit of the existing membership and getting the largest immediate return possible from such investment in current activities.

Compared to those obtained by some of the other professions, the ordinary fees or compensation received by the civil engineers are quite low, and this situation is reflected in the amount of money available for current expenses by the civil engineering organizations. Few, if any, attempts have been made by the civil engineers as such to examine thoroughly the question of compensation, and it has been largely because of this apparent indifference to the fundamentals of individual welfare that a large number of the younger men, who might have been interested in the civil engineering societies, have found an outlet for their energies and an opportunity for helping each other through joining the more progressive American Association of Engineers.

The annual dues of the American Society of Civil Engineers are \$20; those of the American Association of Engineers, \$15, and of most of the state or city societies, $\$ 10$ or less. The number of members in the American Society is over 9,000, and the American Association of Engineers, composed largely of civils, has over 22,000, while in other organizations of civil engineers, the membership is usually below 500. For these dues the members receive an annual report or periodicals, supported in part by advertising.

\section{ENFORCEMENT OF STANDARDS}

As a rule, there have been relatively few attempts to protect the standards of practice in the engineering profession. In fact, the safeguarding of the profession is confined as a rule to the examination of the credentials of the applicant. Once admitted, the case must be extremely flagrant before any action will be taken by the organization. In this respect the condition is similar to that of the older professions where the guild or class distinctions and "professional etiquette" prevent criticism of a fellow member. There have been cases where the derelictions of a member have been considered in executive session by the governing bodies, and presumably warnings have been issued, but these cases are usually carefully guarded, not only from discussion by the public but from the members of the society, themselves.

The usual procedure for dealing with those who violate accepted practice is for the matter to be brought before the governing body and referred to a select committee with a view to going into the details, the whole procedure being highly confidential in its nature and the final decision unknown outside of the small group involved. This has had its good and bad effect; good, in protect- 
ing the engineer from unfair criticism, and bad, in creating a feeling that the members of the profession are indifferent to practices which apparently have grown up without restraint.

The American Association of Engineers, appreciating this condition, has attempted to handle these cases in such a way that the members and the public in general are informed concerning the results and are thus made aware of the fact that improper practices will not be condoned.

The only penalty which may be enforced by a civil engineering society, for violation of its standards, is expulsion from the society, this being largely a matter not made public. The assumption is that no man who has been admitted would be guilty of improper practice after the careful scrutiny given in advance, and that should he fail tolive up to the standards, the fact of dismissal from the society should be adequate punishment.

\section{The Civil Engineer and Public WeLFARE}

The civil engineers with their ultraconservatism have largely refrained from taking part in public affairs, and have not been conspicuous in initiating legislation or regulations for the protection of the public, such, for example, as have characterized the medical profession. It is true that individual members have been prominent in various reforms having to do with better water supply and sewage systems, better roads and bridges, but, as a body, the civil engineers have kept away from active participation in public affairs. In this respect they have not exercised the influence which a group of highly-trained and experienced men should have had.

In a similar way the civil engineers have been extremely cautious in taking any action which might be construed as sustaining or "backing up" the members of the profession in the individual efforts toward improvement of social, economic, or political relations. Many an able civil engineer has been dismissed from public position, or has been severely criticised, without any outward support from the organization to which he belongs. In fact, the caution displayed has been criticised as bordering upon timidity. In this respect, the civil engineers, as a group, do not appear to have a strength in sustaining sound public opinion at all comparable to that of other groups of engineers or to doctors and lawyers.

From what has been stated before, it appears that, in outward appearance at least, the civil engineers, while individually setting a high standard for themselves, have, as group organizations, not been leaders, nor have they developed the ideals of leadership among the younger men. This is undoubtedly due to the type of education which has tended in the past to emphasize in the mind of the young engineer the ideals of modesty and self-effacement, to "let the work speak for itself" and not to put himself forward in expressing opinions. This is in striking contrast to the attitude presented to the young lawyer, who from the outset is instructed as to his duties, as a man and a citizen, to use his best efforts, not only before the courts but in every public meeting; to help in discussion and to take the leadership which is due to the educational advantages which he has had. $\mathrm{He}$ is impressed with the fact that since the public has directly or indirectly contributed to his education, he has a duty in turn to the public to take an interest in its affairs.

The young engineer, on the contrary, impressed with the necessity of accuracy and thoroughness and with the importance of a caution which will 
provide a large factor of safety, is inclined to let public affairs take their course until such time as he may be called upon to assist the men who have become practically the self-constituted leaders of affairs.

The greatest need among civil engineers as a group is to correct this false modesty, and, while maintaining a high standard of professional attainment, couple this with the true conception of the duty of an educated man-never to hold back at times when he can be of service to the public.

\section{Employment}

In the matter of employment the civil engineers, as distinguished from other professional engineers, have tended to lag behind. In fact, one of the strongest criticisms against the civil engineering societies has been their neglect of this whole problem of the welfare of the young men entering the profession, both in the matter of compensation and of employment. The ideals taught in the schools have been largely those of devotion to the work, such as would make it quite improper for the young civil engineer for many years to give consideration to his compensation or personal comfort. In fact, it has been rather a source of pride, that in the construction camps, in survey parties, and elsewhere, the engineer has worked the longest hours, endured the greatest hardship, and has received a pay less than that of the skilled workman or mechanic.

It has been regarded as unprofessional to consider rates of pay, especially for the lower positions in the ranks of civil engineers, and much criticism was showered upon the American Association of Engineers because it did discuss the proper rates of compensation for the men entering upon the civil engineering profession, such as draftsmen, rodmen and instrumentmen. It was urged that such action flavored too much of labor unionism.

In the same way, consideration of methods of securing employment was under the ban for many years, and while some of the higher members of the profession who had reached the grade of consulting engineers were ready to discuss proper fees and rates of pay, these men as employing engineers were not at all keen in considering the claims of the great mass of younger men from whom their ranks would ultimately be recruited. It may be said that until the American Association of Engineers led the way in thedevelopment of an employment service, the principal groups of civil engineers did not look upon this with much favor.

In short, in studying the code of ethics of the civil engineers, the impression is strong that this has been considered largely with reference to the relatively few men who stand near the head of the profession, and has not taken into view the great body of younger men, recently graduated from college, who have the greatest needs, not only as regards practice but also as regards their inexperience in the profession. For this great body, who form the rank and file of civil engineers and who furnish the greater part of the finances of the organizations, there is a special need of a code of ethics and of specific application of such a code, in order that they may properly pursue a middle course, avoiding, on the one hand, the selfish practices which are attributed to some of the labor unions, and, on the other hand, the extremes of an over-sensitive conscience or timidity which has kept the civil engineers out of the larger affairs of daily life. 


\title{
Ethics of the Electrical Engineer
}

\author{
By Carl Hering, D.Sc. \\ Consulting Electrical Engineer, Philadelphia, Pennsylvania
}

\section{$\mathrm{P}^{\mathrm{n}}$} ROFESSIONAL engineers deal primarily with the forces of nature and are, therefore, governed in their work by the laws of nature; as mother nature demands and insists upon absolute obedience to her laws from which there is no appeal and which cannot be circumvented, the engineer is, by the very nature of his profession, brought up to respect and obey the laws which are fundamental to his work. Any violation of these laws is certain to bring its own punishment with it, even without a trial, either in showing the ignorance and therefore unfitness of the violator, or, what is worse, the deliberate practice of what he knew was wrong. Moreover, many human lives are often at stake when an engineering structure fails; hence the engineer realizes that his responsibility in many cases is very great.

As has often been said by way of comparison, the physician can bury his mistakes six feet under the ground, the lawyer can pass the blame to the jury, court, or witnesses, and the minister can often find a quotation from the Bible which, taken literally, may seem to uphold him in a mistake he may have made; but when the engineer makes a mistake or violates the laws which are fundamental to his profession, he cannot hide the blame or pass it to others. Since, then, there is generally no question who is responsible, and no escape from censure, he must be doubly sure of what he does and how he does it. His profession is therefore by its very nature on a high plane, as far as it concerns obedience to the laws of nature, a thorough knowledge of his branch of learning, which involves a higher education extending over many years, conscientiousness, and regard for the effect of his work on others.

Training in such an atmosphere cannot fail to have an important bearing on the ethics of engineering conduct; the records of the professional lives of many noted engineers bear this out, as does also the ruination, professionally as engineers, of those who have violated the principles of a high code of ethics. "The engineer's intellectual relations with his subject involve a contact with nature and her laws that breeds straight thinking and directness of character and for these the world is constantly according him a higher and more honorable place." ${ }^{1}$

\section{Engineering as a Profession}

That engineering is recognized as one of the so-called "learned professions" and as such is in a class with the medical, legal and other professions, is probably now generally conceded, at least when the nature of the work is limited to true engineering as distinguished from commercial work, and is based on high educational qualifications acquired at a college of good standing, supplemented by years of experience and training and the intelligent application of such knowledge. The requirements in educational qualifications and training are quite as great, if not greater than for some of the other professions. But to the mind of the public, unfortunately, the term "engineer" often means the mechanic who operates a locomotive or some other form of engine.

The preceding statements apply to the profession of engineering in general,

1 (Gano Dunn.) 
embracing four main divisions, electrical, mechanical, civil and mining, with many sub-divisions. Though the particular codes of ethics of the various branches may differ somewhat, owing to the differences in the nature of the work, in general they are based on the leading, centuries-old principle, "Do unto others as you would be done by," and not on that modern version of it, used by some business men, "Do others or they will do you."

The "Code of Principles of Professional Conduct" adopted by the American Institute of Electrical Engineers is published elsewhere in this volume. ${ }^{2}$ The present article will be limited to replies to some of the questions which the author has been asked, concerning his profession.

The American Institute of Electrical Engineers, organized in 1884 and having a membership of between 12,000 and 13,000 , is the only large, national society of electrical engineers, including in its membership all the leading men of this division of the engineering profession. It may be said to be the law-making organization of this division, and its high motives may be relied upon. It is supported by membership dues and has three grades of members, of which the much coveted highest grade, that of fellow, is restricted to those who have certain high qualifications. Young men have easy access to associate membership; for the advancement to full membership definite requirements are necessary, referring chiefly to the applicant's record and to the reputation he has gained by his work in the past. There are many other societies and organizations dealing with special branches and they may have their own code of ethics, but this is the senior or parent institution for the electrical engineering profession.

${ }^{2}$ See Appendix, page 274.
That its members have respect for high principles of proper professional conduct is indicated by the fact that no member has ever yet been expelled, though in one case a member whose conduct was being investigated by the Committee on Professional Conduct, resigned before the case was concluded, and his resignation was promptly accepted. A small number of other cases have been considered by this Committee from time to time. At present a recommendation is under consideration that a brief statement of such cases and the actions taken be published in the monthly publication of the Institute, without giving any names.

The clause in the constitution governing the subject of expulsion is as follows:

Sec. 15. Upon the written request of ten or more Fellows, Members or Associates that, for cause stated therein, a Fellow, Member or Associate of the Institute be expelled, the Board of Directors shall consider the matter, and if there appears to be sufficient reason, shall advise the accused of the charges against him. He shall then have the right to present a written defence, and to appear in person or by duly authorized representative before a meeting of the Board of Directors, of which meeting he shall receive notice at least twenty days in advance. Not less than two months after such meeting, the Board of Directors shall finally consider the case, and if in the opinion of the Board of Directors a satisfactory defence has not been made, and the accused member has not in the meantime tendered his resignation, he shall be expelled.

\section{The Need for Principles of Engineering Conduct}

From the nature of the different engineering branches, differences arise which have some bearing on professional conduct. Under the broad term of electrical engineers, there are included salesmen, contractors, manu- 
facturers, administrators, organizers, financiers, promoters, etc., many of whom may have started as college-bred engineers, but have branched off into these other vocations, for which they were often very well fitted by reason of their engineering training. Their interests are, however, sometimes directly opposed. To manufacturers and those entrusted with the selling of a product or project, "the exigencies of selling are so constantly forced upon them, that it produces in their circles a commercial atmosphere quite at variance with strict professional views," to quote from a leading engineering journal. Technical journals themselves may not always be free from the influence of their advertisers. Another technical journal last year said editorially, "It is to be hoped that the year 1921 will see real progress in the establishment of codes of ethics in the various engineering societies, or, better, the establishment of general fundamental principles of engineering ethics on which the individual societies may build." Still another technical journal asks, "Is engineering a profession or a business?" and implies that it must be one or the other, stating that "we are at the parting of the ways." This distinction refers to the modern large organizations, as distinguished from the individual engineer, in conducting engineering work; it implies the old saying that "corporations have no souls." The differences between the ethics of such large organizations and of the individual engineer is a subject of discussion which space does not permit going into here.

Within the near past, another departure of a somewhat psychological nature has been added to the engineering profession, that of the science of dealing with men, as exemplified in the legend in the great National Engineering Library in New York
City, which states as a conception of engineering: "Engineering-the art of organizing and directing men, and of controlling the forces and materials of nature for the benefit of the human race." The last part of this legend was formerly one of the definitions of an engineer; the former clause has more recently been added, though not by unanimous consent. In the opinion of some, the term engineering is being broadened too far.

It is often difficult to draw sharp lines between the many different practices, as to where true engineering begins and ends. The title of "engineer" is a coveted one, and rightly so, as long as it implies a long and difficult course of education and training, and it is therefore natural that its appropriation is broadening. A code of ethics is naturally a different matter for one who deals with the application of nature's laws of matter and energy for the benefit of mankind, than for one who deals merely with getting the largest number of dollars; though of course the true engineer must of necessity also consider the cost of projects. For the purposes of the present article, however, the term professional engineer may be supposed to apply to those who occupy themselves exclusively with the true profession of engineering, in its older sense of applying the laws of matter and energy to the benefit of mankind by the design, construction and use of engineering structures. The statement of Francis Bacon in the preface to his "Maxims of the Law" applies to professional engineers as well: "I hold every man a debtor to his profession, from the which as men of course do seek to receive contenance and profit, so ought they of duty to endeavor themselves by way of amends to be a help and ornament thereunto." 
The Engineer and Public Service

As the progress of the world, the comforts of man and his ability to produce, are so very largely due to the work of the engineer, his work is of the very greatest importance; he therefore naturally interests himself also in the public welfare in behalf of which he should "be ready to apply his special knowledge, skill and training for the use and benefit of mankind," and with loyalty to his country, evidence of which was shown in the recent War, which, to a greater extent than ever before, was dependent on the skill of the engineer.

In connection with testimony by engineers in legal cases, a clause in one of the engineering codes says: "To render reports or testimony intended to deceive is highly unprofessional," a maxim which contrasts with the guiding principle of some lawyers: "Win the case; win it honestly if you can, but win it."

The engineer's work is often connected with some form of public service and he is therefore concerned with the public and with public welfare. His obligations to serve the public conscientiously to the best of his abilities are thereby instilled into him; his natural repugnance to act against the interest of the public, or of those in his charge, when urged to do so by his less scrupu- lous superior officer, perhaps a politician, a contractor or a financier, has cost many an engineer his position.

Untiring efforts are made by those of experience in the profession to advance the standards of education and training of the rising generation of engineers in the schools and colleges; the subject is frequently discussed at the sessions of the American Institute of Electrical Engineers between those who know what is needed in actual practice and those who do the teaching and training; both willingly coöperate to the great advantage of the student.

Any special recruiting for the profession of electrical engineering seems hardly necessary, as the great interest taken by many young men in this branch of engineering seems to be sufficient.

An employment service is conducted by the Institute; in general, any form of service pertaining to electrical engineering, either to its members, the profession, the public, or the government, which is of such a nature that it can best be done by this large national organization, including in its membership all the leading electrical engineers of the country and many in foreign countries, is willingly undertaken and intelligently carried out. In many instances, the Institute has set an example to others.

\title{
Procedure in Developing Ethical Standards Adopted by the American Association of Engineers
}

\author{
By H. W. Clausen
}

Treasurer of the American Association of Engineers; Chairman, Practice Committee, American Association of Engineers

$\mathrm{T}$ HE maintenance of the proper ethical relations of the professional engineer both with the public and with his fellow engineers is becoming of great importance in the effort to develop the service of the engineer to its maximum of usefulness. Clearly, one of the essentials to a constructive and vigorous policy leading to the harmonious coöperation of all concerned, 